Archives of Agriculture and Environmental Science

\title{
Effectiveness of fulvic acid to the growth of Swietenia macrophylla King. with addition phosphate at post mining land in Indonesia
}

\section{Basuki Wasis* (iD) and Dimas Okta Arifani}

Department of Silviculture, Faculty of Forestry, Bogor Agricultural University (IPB University), Bogor 16680, West Java, INDONESIA

"Corresponding author's E-mail: basuki_wasis@yahoo.com

\section{ARTICLE HISTORY}

Received: 16 May 2019

Revised received: 26 May 2019

Accepted: 05 June 2019

\section{Keywords}

Fulvic acid

Phosphate fertilizer

Post mining

Revegetation

Swietenia macrophylla King.

\begin{abstract}
Mining activities would cause a decrease in carrying capacity and land function due to erosion, changes in soil structure, loss of vegetation, pollution, nutrient depletion and increasing $\mathrm{Al}^{3+}$ levels so that soil $\mathrm{pH}$ conditions will be low. This study aims to increase the Swietenia macrophylla King growth response at the gold mining land that can be used as a tool for consideration in revegetation activities. The design used in this experiment was a complete randomized design (CRD) factorial with 2 factors. The first factor was the application of fulvic acid $\left(F_{0}=\right.$ control, $F_{1}=$ concentration of $2 \%$ ( $2 \mathrm{ml}$ of fulvic acid plus $98 \mathrm{ml}$ of water), $F_{2}=3 \%$ ( $3 \mathrm{ml}$ of fulvic acid plus $97 \mathrm{ml}$ of water), $\mathrm{F}_{3}=5 \%$ ( $5 \mathrm{ml}$ of fulvic acid plus $95 \mathrm{ml}$ of water) and the second factor was the application of phosphate fertilizer $\left(P_{0}=0 \mathrm{~g} /\right.$ polybag, $P_{1}=10 \mathrm{~g} /$ polybag, $P_{2}=15 \mathrm{~g} /$ polybag and $\mathrm{P}_{3}=20 \mathrm{~g} /$ polybag) were used for preparation of different treatments. The treatment of fulvic acid significantly affected the growth of S. macrophylla for parameters of diameter, total dry weight, and root dry weight of $S$. macrophylla. The single effect of phosphate fertilizer treatment had a significant effect on high growth, diametert, total wet weight, and total dry weight of S. macrophylla. The interaction of fulvic acid and phosphate fertilizer significantly affected the diameter, total dry weight and root dry weight of S. macrophylla. $\mathrm{F}_{2} \mathrm{P}_{3}$ treatment (3\% fulvic acid and $20 \mathrm{~g}$ phosphate fertilizer is the best combination treatment. Therefore, application of fulvic acid and phosphate fertilizer on post mining soil improves soil fertility and decreases Al elements which are toxic to plants.
\end{abstract}

(C)2019 Agriculture and Environmental Science Academy

Citation of this article: Wasis, B. and Arifani, D.O. (2019). Effectiveness of fulvic acid to the growth of Swietenia macrophylla King. with addition phosphate at post mining land in Indonesia. Archives of Agriculture and Environmental Science, 4(2): 213-218, https://dx.doi.org/10.26832/24566632.2019.0402013

\section{INTRODUCTION}

Mining activities provide substantial regional and state income. However, mining activities also have a negative impact on damage to forest ecosystems, loss of soil solum, damage to soil horizons, damage to soil properties, erosion and environmental pollution (Wasis and Angga, 2017, Wasis et al., 2018). Regulation requires every company holding an IUP (mining business license) to improve and reduce the negative impact of mining activities carried out. In line with the regulations listed in Law, Indonesia No. 41 of 1999 concerning Forestry Article 45 Paragraph 2, reclamation in former forest areas of mining areas must be carried out by mining permit holders in accordance with the stages of mining activities. Reclamation and rehabilitation are mandatory activities on ex-mining land, but in the implementation of reclamation and rehabilitation activities on post mining land there are obstacles, namely the condition of marginal land. Former gold mine land has chemical properties that do not support plant growth, which has a low value of cation exchange capacity, low soil fertility, low infiltration rate, resulting in inundation that has an impact on increasing alumunium (Al) concentrations that are toxic (Wahyudi, 2007; Wasis and Angga, 2017). Determination of the type that is adaptive to damaged soil conditions needs to be done, one type of adaptive that can grow on marginal land is Swietenia macrophylla King. 
Constraints in planting S. macrophylla in fact often fail which are characterized by slow, stunted growth and often experience symptoms of necrosis. Failures that occur are suspected of mining residual minerals and are toxic to plants. The toxicity caused can be overcome by adding fulvic acid (Wahyudi, 2007; Wasis and Angga, 2017). The addition of fulvic acid can increase $\mathrm{pH}$ and reduce the content of minerals that are toxic to plants, but the effectiveness of fulvic acid is influenced by the presence of phosphates available in the soil (Wahyudi, 2007). This study was conducted to determine the effect of phosphate on the effectiveness of fulvic acid in the growth of S. macrophylla plants on ex-gold mine land.

\section{MATERIALS AND METHODS}

\section{Experimental design}

The study was conducted in January - April 2017. Toxic soil samples were taken from the PT Cibaliung Sumberdaya in Banten Regency, Banten Province, Indonesia. Testing of toxic nutrient minerals was carried out at the Laboratory of Chemical and Soil Fertility, Department of Land Resources, Faculty of Agriculture, IPB University. Observation of the growth of $S$. macrophylla in the Greenhouse of the Laboratory of Forest Ecology, Department of Silviculture, Faculty of Forestry, IPB University, Bogor, Indonesia. The tools used in this study were the Global Positioning System (GPS), location maps, hoes, pitchforks, polybags of size $10 \mathrm{~cm} \times 15 \mathrm{~cm}$ (diameter $\times$ height), $50 \mathrm{~cm}$ ruler, sterophome bowl, plant sprinklers, digital cameras, analytical scales 4 digits, ovens, label paper, tallysheet, markers. The material used is the seeds of S. macrophylla. Phosphate fertilizers in the form of SP36, fulvic acid, toxic soil media, compost in the form of manure, and water.

\section{Soil sampling and soil analysis}

Our soil samples were taken purposive sampling, in locations that have high $\mathrm{Al}$ or Fe content, and low $\mathrm{pH}$. The soil tested came from composite soil from 5 locations adjacent to each other. The distance between pickup points is $2-3 \mathrm{~m}$ and at the third point or midpoint does mapping using GPS. The pattern of soil sampling can be seen in Figure 1. Furthermore, soil sampling is carried out by drilling techniques with a depth of approximately $30 \mathrm{~cm}$ with a diameter of approximately $15 \mathrm{~cm}$ below the surface of the ground after the gold mine mine. The analysis of soil properties includes $\mathrm{pH}$, cation exchange capacity (CEC), $\mathrm{C}$ organic, nitrogen, aluminum (Al), calcium (Ca), magnesium (Mg) and phosphorus (P).

\section{Preparation of cultivation media and plantation}

Land originated from post gold mining land at PT Cibaliung Sumberdaya, Banten Regency, Banten Province, Indonesia. The filtered soil is then sieved using a sieve made of $1 \mathrm{~m} \times 1 \mathrm{~m}$ sand wire to separate the gravel from the ground. Plant media used in the form of soil and compost mixed with a ratio of $3: 1$. Then put into a polybag with a size of $10 \mathrm{~cm} \times 15 \mathrm{~cm}$.
Seedlings of S. macrophylla are weaned into a planting medium that contains soil from post mining land. Weaning is done in the afternoon. The steps taken in weaning the seedlings of S. macrophylla are removed from the previous planting media and cleaned. The root of the seed is then soaked in water for 30 minutes. Then the seedlings of $S$. macrophylla are planted according to the prescribed treatment. Seedling maintenance is carried out by watering (field capacity) every morning around 07.00 WIB and in the afternoon at 17.00 WIB, if the soil still feels wet it is not necessary to do watering again. Other maintenance is carried out in the form of eradicating weeds.

\section{Data collection}

Data collection was conducted every week in the period of January - April 2017. Data collection was done by doing measurement of height and diameter of the seedlings of S. macrophylla. Beside that, total wet weight and total dry weight measurements of S. macrophylla were done after the harvesting. The harvested plants of S. macrophylla were separated between the root and shoot. Then, seedlings of S. macrophylla were dried off in the oven at $80^{\circ} \mathrm{C}$ as long as 24 hours (Wasis and Fathia, 2011; Wasis and Angga, 2017). After that, S. macrophylla seedlings were weighed again to know the dry weight. In other hand, two samples of soil / tailing (planting medium) were analyzed to know the soil characteristics. The two samples of these medium were soil / medium with control treatment and the best treatment which gave the best growth prefromance of S. macrophylla.

\section{Methodology and data analysis}

Experimental design used was factorial completely randomized design with two factors. The first factor is the treatment of fulvic acid, which is $\mathrm{F}_{0}=$ control, $\mathrm{F}_{1}=$ concentration of $2 \%(2 \mathrm{ml}$ of fulvic-acid plus $98 \mathrm{ml}$ of water), $F_{2}=3 \%$ ( $3 \mathrm{ml}$ of fulvic-acid plus $97 \mathrm{ml}$ of water), $\mathrm{F}_{3}=5 \%$ ( $5 \mathrm{ml}$ of fulvic-acid plus $95 \mathrm{ml}$ of water). The second factor is phosphate dosing, namely $P_{0}=0 \mathrm{~g} /$ polybag, $\mathrm{P}_{1}=10 \mathrm{~g} /$ polybag, $\mathrm{P}_{2}=15 \mathrm{~g} /$ polybag and $\mathrm{P}_{3}=20 \mathrm{~g} /$ polybag. So that the total plant used is 80 plants. Data obtained from observations and measurements in the field were analyzed using experimental designs, which can be described in a linear method (Stell and Torries, 1991; Mattjik and Sumertajaya, 2006). Only if there is significant effect, Duncan's Multiple Range Test will be measured for getting further statistic data.

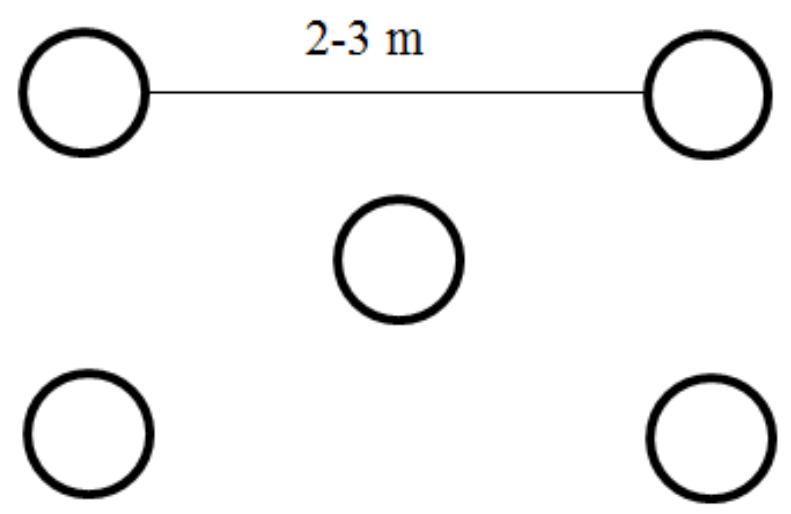

Figure 1. Technique used for collection of soil samples during the study. 


\section{RESULTS AND DISCUSSION}

Effects of fulvic-acid and phosphate treatments on the growth parameters of S. macrophylla

The results of analysis of variance showed that a single treatment of fulvic acid had a significant effect on growth in diameter, total dry weight, and roots dry weight of $S$. macrophylla. The single treatment of phosphate fertilizer had a significant effect on high, diameter, total wet weight and total dry weight of $S$. macrophylla. While the interaction treatment significantly affected the growth of diameter, total dry weight, and root dry weight of S. macrophylla (Table 1).

The best application of phosphate fertilizer is shown by giving $20 \mathrm{~g}$ of phosphate fertilizer $\left(\mathrm{P}_{3}\right)$ with an average plant growth of $18.84 \mathrm{~cm}$ of $S$. macrophylla and an increase in the percentage of control by $52 \%$ (Table 2). According to Wasis and Noviani (2010), the provision of fertilizer provides better results for the growth of plant seeds, but beyond that there are external factors that influence the growth of plant seeds in addition to the provision of inorganic fertilizers.
Duncan's test results showed that the administration of fulvic acid with a concentration of $1 \%$ and the treatment of phosphate fertilizer at $20 \mathrm{~g}\left(\mathrm{~F}_{1} \mathrm{P}_{3}\right)$ was the best combination treatment, and had a significant effect on all treatments tested, the combination treatment had a growth rate of $3.36 \mathrm{~cm}$. of $S$. macrophylla with a percentage increase in diameter growth to control $\left(\mathrm{F}_{0} \mathrm{P}_{0}\right)$ of $42 \%$. The lowest growth of the diameter is in the treatment of the combination of fulvic acid with a concentration of $3 \%$ and phosphate fertilizer treatment of $10 \mathrm{~g}$ $\left(\mathrm{F}_{2} \mathrm{P}_{1}\right)$ which has a growth average diameter of $1.64 \mathrm{~cm}$ of $S$. macrophylla and a percentage decrease in diameter growth to control $\left(\mathrm{F}_{0} \mathrm{P}_{0}\right)$ of $31 \%$ (Table 3$)$.

The Duncan test results showed that the best treatment was 15 $\mathrm{g}$ of phosphate fertilizer $\left(\mathrm{P}_{2}\right)$ with a total wet weight of $23.56 \mathrm{~g}$ and an increase in the percentage of control $\left(\mathrm{P}_{0}\right)$ of $40 \%$. These results indicate that the treatment of fulvic acid at a dose of $5 \%$ is not sufficient for nutrient requirements for plants, it is shown that a single treatment and interaction treatment has no significant effect (Table 4). $\mathrm{N}$ nutrient content in fulvic acid ranges from $0.7-2.6 \%$ (Tan, 1991).

Table 1. Effect of fulvic acid and phosphate fertilizer impact on growth of S. macrophylla.

\begin{tabular}{llll}
\hline \multirow{2}{*}{ Parameter } & \multicolumn{2}{c}{ Treatment } \\
\cline { 2 - 4 } & Fulvic acid & Phosphate fertilizer & Fulfic acid and phosphate fertilizer \\
\hline Height & $0.996 \mathrm{tn}$ & $0.001^{*}$ & $0.107 \mathrm{tn}$ \\
Diameter & $0.023^{*}$ & $0.002^{*}$ & $0.005^{*}$ \\
Total wet weight & $0.986 \mathrm{tn}$ & $0.005^{*}$ & $0.060 \mathrm{tn}$ \\
Total dry weight & $<.0001^{*}$ & $0.021^{*}$ & $0.050^{*}$ \\
Root dry weight & $<.0001^{*}$ & $0.068 \mathrm{tn}$ & $0.018^{*}$ \\
Root shoot ratio & $0.255 \mathrm{tn}$ & $0.237 \mathrm{tn}$ & $0.157 \mathrm{tn}$ \\
\hline
\end{tabular}

Table 2. Duncan's test of the effect of phosphate fertilizer on the high increase in S. macrophylla.

\begin{tabular}{lll}
\hline Treatment & Average height growth $(\mathrm{cm})$ & Percent increase (\%) \\
\hline $\mathrm{P}_{0}$ & $12.4125 \mathrm{a}$ & $0 \%$ \\
$\mathrm{P}_{1}$ & $13.4000 \mathrm{a}$ & $8 \%$ \\
$\mathrm{P}_{2}$ & $13.6438 \mathrm{a}$ & $10 \%$ \\
$\mathrm{P}_{3}$ & $18.8437 \mathrm{~b}$ & $52 \%$ \\
\hline
\end{tabular}

Table 3. Duncan Test effect of combination treatment on the growth of diameter of S. macrophylla.

\begin{tabular}{lll}
\hline Treatment & Average diameter growth $(\mathrm{cm})$ & Percent increase (\%) \\
\hline $\mathrm{F}_{1} \mathrm{P}_{3}$ & $3.3650 \mathrm{a}$ & $42 \%$ \\
$\mathrm{~F}_{1} \mathrm{P}_{2}$ & $3.1200 \mathrm{ab}$ & $32 \%$ \\
$\mathrm{~F}_{2} \mathrm{P}_{3}$ & $2.9525 \mathrm{abc}$ & $24 \%$ \\
$\mathrm{~F}_{2} \mathrm{P}_{2}$ & $2.6950 \mathrm{abcd}$ & $14 \%$ \\
$\mathrm{~F}_{0} \mathrm{P}_{3}$ & $2.6900 \mathrm{abcd}$ & $13 \%$ \\
$\mathrm{~F}_{3} \mathrm{P}_{2}$ & $2.6700 \mathrm{abcd}$ & $13 \%$ \\
$\mathrm{~F}_{0} \mathrm{P}_{2}$ & $2.6200 \mathrm{abcd}$ & $10 \%$ \\
$\mathrm{~F}_{1} \mathrm{P}_{1}$ & $2.6100 \mathrm{abcd}$ & $10 \%$ \\
$\mathrm{~F}_{0} \mathrm{P}_{1}$ & $2.5550 \mathrm{abcd}$ & $8 \%$ \\
$\mathrm{~F}_{3} \mathrm{P}_{1}$ & $2.4100 \mathrm{bcde}$ & $2 \%$ \\
$\mathrm{~F}_{0} \mathrm{P}_{0}$ & $0 \%$ \\
$\mathrm{~F}_{1} \mathrm{P}_{0}$ & $2.3725 \mathrm{bcde}$ & $0 \%$ \\
$\mathrm{~F}_{3} \mathrm{P}_{3}$ & $2.3625 \mathrm{bcde}$ & $-2 \%$ \\
$\mathrm{~F}_{2} \mathrm{P}_{0}$ & $2.3150 \mathrm{bcde}$ & $-7 \%$ \\
$\mathrm{~F}_{3} \mathrm{P}_{0}$ & $2.1950 \mathrm{cde}$ & $-17 \%$ \\
$\mathrm{~F}_{2} \mathrm{P}_{1}$ & $1.9675 \mathrm{de}$ & $-31 \%$ \\
\hline Table 4. Duncan Test single effect of phosphate fertilizer on total wet weight of S. macrophylla. & \\
\hline Treatment & $1.6375 \mathrm{e}$ & Percent increase (\%) \\
\hline $\mathrm{P}_{2}$ & Average total wet weight (g) & $40 \%$ \\
$\mathrm{P}_{3}$ & $23.5569 \mathrm{a}$ & $29 \%$ \\
$\mathrm{P}_{1}$ & $21.6113 \mathrm{a}$ & $25 \%$ \\
$\mathrm{P}_{0}$ & $21.0369 \mathrm{a}$ & $0 \%$ \\
\hline \hline
\end{tabular}


Table 5. Duncan test effect of treatment combinations on total dry weight of S. macrophylla.

\begin{tabular}{lll}
\hline Treatment & Average total dry weight $(\mathrm{g})$ & Percent increase (\%) \\
\hline $\mathrm{F}_{2} \mathrm{P}_{3}$ & $12.6675 \mathrm{a}$ & $57 \%$ \\
$\mathrm{~F}_{3} \mathrm{P}_{2}$ & $12.3175 \mathrm{ab}$ & $53 \%$ \\
$\mathrm{~F}_{2} \mathrm{P}_{2}$ & $12.1350 \mathrm{ab}$ & $50 \%$ \\
$\mathrm{~F}_{1} \mathrm{P}_{2}$ & $11.9800 \mathrm{ab}$ & $48 \%$ \\
$\mathrm{~F}_{3} \mathrm{P}_{1}$ & $11.2350 \mathrm{abc}$ & $39 \%$ \\
$\mathrm{~F}_{1} \mathrm{P}_{1}$ & $11.1175 \mathrm{abc}$ & $38 \%$ \\
$\mathrm{~F}_{3} \mathrm{P}_{0}$ & $10.8850 \mathrm{abc}$ & $35 \%$ \\
$\mathrm{~F}_{2} \mathrm{P}_{1}$ & $9.8650 \mathrm{abcd}$ & $22 \%$ \\
$\mathrm{~F}_{3} \mathrm{P}_{3}$ & $9.4450 \mathrm{abcd}$ & $17 \%$ \\
$\mathrm{~F}_{1} \mathrm{P}_{3}$ & $8.8700 \mathrm{bcd}$ & $10 \%$ \\
$\mathrm{~F}_{1} \mathrm{P}_{0}$ & $8.1650 \mathrm{~cd}$ & $1 \%$ \\
$\mathrm{~F}_{0} \mathrm{P}_{0}$ & $8.0675 \mathrm{~cd}$ & $0 \%$ \\
$\mathrm{~F}_{0} \mathrm{P}_{2}$ & $7.6400 \mathrm{~cd}$ & $-5 \%$ \\
$\mathrm{~F}_{0} \mathrm{P}_{3}$ & $7.2675 \mathrm{~d}$ & $-10 \%$ \\
$\mathrm{~F}_{0} \mathrm{P}_{1}$ & $7.0350 \mathrm{~d}$ & $-13 \%$ \\
$\mathrm{~F}_{2} \mathrm{P}_{0}$ & $7.0175 \mathrm{~d}$ & $-13 \%$ \\
\hline
\end{tabular}

Table 6. Duncan test the effect of treatment combinations on the dry weight of roots of S. macrophylla.

\begin{tabular}{lll}
\hline Treatment & Average root dry weight (g) & Percent increase (\%) \\
\hline$F_{2} \mathrm{P}_{3}$ & $4.1400 \mathrm{a}$ & $91 \%$ \\
$\mathrm{~F}_{2} \mathrm{P}_{2}$ & $3.9400 \mathrm{ab}$ & $82 \%$ \\
$\mathrm{~F}_{3} \mathrm{P}_{0}$ & $3.6550 \mathrm{ab}$ & $68 \%$ \\
$\mathrm{~F}_{3} \mathrm{P}_{1}$ & $3.6450 \mathrm{ab}$ & $68 \%$ \\
$\mathrm{~F}_{1} \mathrm{P}_{2}$ & $3.5450 \mathrm{ab}$ & $63 \%$ \\
$\mathrm{~F}_{3} \mathrm{P}_{2}$ & $3.5000 \mathrm{ab}$ & $61 \%$ \\
$\mathrm{~F}_{2} \mathrm{P}_{1}$ & $2.9575 \mathrm{abc}$ & $36 \%$ \\
$\mathrm{~F}_{3} \mathrm{P}_{3}$ & $2.7650 \mathrm{abcd}$ & $27 \%$ \\
$\mathrm{~F}_{1} \mathrm{P}_{3}$ & $2.6525 \mathrm{abcd}$ & $22 \%$ \\
$\mathrm{~F}_{0} \mathrm{P}_{0}$ & $2.1700 \mathrm{bcd}$ & $0 \%$ \\
$\mathrm{~F}_{1} \mathrm{P}_{0}$ & $1.6600 \mathrm{~cd}$ & $-24 \%$ \\
$\mathrm{~F}_{0} \mathrm{P}_{2}$ & $1.5450 \mathrm{~cd}$ & $-29 \%$ \\
$\mathrm{~F}_{1} \mathrm{P}_{1}$ & $1.5075 \mathrm{~cd}$ & $-31 \%$ \\
$\mathrm{~F}_{0} \mathrm{P}_{3}$ & $1.3425 \mathrm{~cd}$ & $-38 \%$ \\
$\mathrm{~F}_{2} \mathrm{P}_{0}$ & $1.3025 \mathrm{~cd}$ & $-40 \%$ \\
$\mathrm{~F}_{0} \mathrm{P}_{1}$ & $1.0500 \mathrm{~d}$ & $-52 \%$ \\
\hline
\end{tabular}

Table 7. Effects of most effective fulvic acid and phosphate treatment $\left(\mathrm{F}_{2} \mathrm{P}_{3}\right)$ on the characteristics of post mining soil.

\begin{tabular}{llll}
\hline Parameter & Post mining soil & Fulvic acid and and phosphate fertilizers $\left(\mathbf{F}_{2} \mathbf{P}_{3}\right)$ & Percent change $(\%)$ \\
\hline pH & 3.34 & 4.92 & +1.58 \\
Organic C (\%) & 3.02 & 11.16 & +8.14 \\
Total nitrogen (\%) & 0.06 & 0.26 & +0.20 \\
Phosphorous (ppm) & 1.99 & 1502.21 & +1500.22 \\
Calcium (Ca cmol/kg) & 0.59 & 9.41 & +8.82 \\
Magnesium $(\mathrm{Mg} \mathrm{cmol} / \mathrm{kg})$ & 0.25 & 2.70 & +2.45 \\
Potasium $(\mathrm{K} \mathrm{cmol} / \mathrm{kg})$ & 0.10 & 4.59 & +4.49 \\
Sodium $(\mathrm{Na} \mathrm{cmol} / \mathrm{kg})$ & 0.18 & 1.43 & +1.25 \\
CEC (cmol/ $/ \mathrm{kg})$ & 9.89 & 15.66 & +5.77 \\
Alumunium $(\mathrm{cmol} / \mathrm{kg})$ & 10.44 & 0.00 & -10.44 \\
\hline
\end{tabular}


The Duncan test results showed that the best combination treatment was $3 \%$ fulvic acid and $20 \mathrm{~g}$ phosphate fertilizer $\left(\mathrm{F}_{2} \mathrm{P}_{3}\right)$ which had a total dry weight of $12.67 \mathrm{~g}$ of S. macrophylla with a percentage of $57 \%$ increase in control (Table 5). Total dry weight of S. macrophylla is the main parameter used as a reference because it shows the main biomass of plants which is the end result of the ecophysiological process, which expresses environmental (ecological) and physiological factors (Wasis and Noviani, 2010).

The Duncan test results in Table 6 show that the treatment of $\mathrm{F}_{2} \mathrm{P}_{3}$ (3\% fulvic acid and $20 \mathrm{~g}$ phosphate fertilizer) is the best combination treatment with an average dry root weight of 4.14 $\mathrm{g}$ of S. macrophylla and a $91 \%$ increase in the percentage of control (Table 6). Fulvic acid stimulate growth plants through a variety of mechanisms that appear from several parameters, one of which is root weight. Fulvic acid absorbed by plants can increase cell permeability so that nutrient uptake also increases (Hardjowigeno, 2003; Wahyudi, 2007).

In Figure 2, overall plant shoot growth of S. macrophylla tends to be higher than root, which has a value above 1 . The treatment of fulvic acid with a concentration of $5 \%\left(F_{3}\right)$ showed a relatively plant growth pattern which has a root shoot ratio of 1 (one) which means that there is a growth balance of roots and shoots of $S$. macrophylla. The value of root shoot ratio can be used to see the balance between root capability in absorbing water and nutrients as well as the ability of plant shoot in the process of transpiration and the rate of photosynthesis. Plant growth is called has well performance when it has a value of shoot root ratio ranging from 1-3 (Mokany, Raison and Prokushkin, 2006; Wasis and Andika, 2017).
Effects of fulvic-acid and phosphate treatments on the soil characteristics

This study shows that the treatment increases soil $\mathrm{pH}$ by 1.58 , which is from 3.34 on post mining soil to 4.93 in the best treatment $\left(\mathrm{F}_{2} \mathrm{P}_{3}\right)$ (Figure 2). This is caused by the addition of fulvic acid and phosphate fertilizer on post mining soil. The addition of compost or organic matter has an effect on soil improvement, especially the physical and chemical properties of the soil. The addition of organic matter in the form of compost has an effect on changes in $\mathrm{pH}$. Organic acids can bind $\mathrm{H}^{+}$ions through carboxyl groups that have a negative charge (Ani, 2007; Hardjowigeno, 2003).

The treatment of fulvic acid and phosphate fertilizer reduced toxic Al levels on post mining soil by $10.44 \mathrm{cmol} / \mathrm{kg}$ where from $10.44 \mathrm{cmol} / \mathrm{kg}$ to post mining soil it became $0 \mathrm{cmol} / \mathrm{kg}$ at the best treatment $\left(\mathrm{F}_{2} \mathrm{P}_{3}\right)$. The decrease in $\mathrm{Al}$ value is due to the treatment of fulvic acid and phosphate fertilizer to be able to bind to free $\mathrm{Al}^{3+}$ ions, causing $\mathrm{Al}$ levels to decrease significantly. The decrease in $\mathrm{Al}$ will increase the available $\mathrm{P}$-land because $\mathrm{Al}^{3+}$ is a metal that can bind $\mathrm{P}$ to form compounds that cannot dissolve and reduce soil $\mathrm{pH}$ due to the increased concentration of $\mathrm{H}^{+}$ions in the soil (Tan, 1993; Rahmawati, 2011; Prengki et al., 2017).

The overall treatment of fulvic acid and phosphate fertilizer increases macro nutrients compared to post mining soil. It can be seen in Table 7 that the nutrient content in the soil experienced a significant increase such as nutrients $\mathrm{N}, \mathrm{P}, \mathrm{K}, \mathrm{Ca}$ and $\mathrm{Mg}$. Cation exchange capacity is one of the important parameters in determining soil fertility. In table 7 , the treatment of fulvic acid and phosphate fertilizer can increase the CEC on land by 5.77 $\mathrm{cmol} / \mathrm{kg}$, from $9.89 \mathrm{cmol} / \mathrm{kg}$ to post mining soil to $15.66 \mathrm{cmol} /$ $\mathrm{kg}$ at the best treatment $\mathrm{F}_{2} \mathrm{P}_{3}$. This shows that the treatment of fulvic acid will cause an improvement in soil CEC (Table 7).

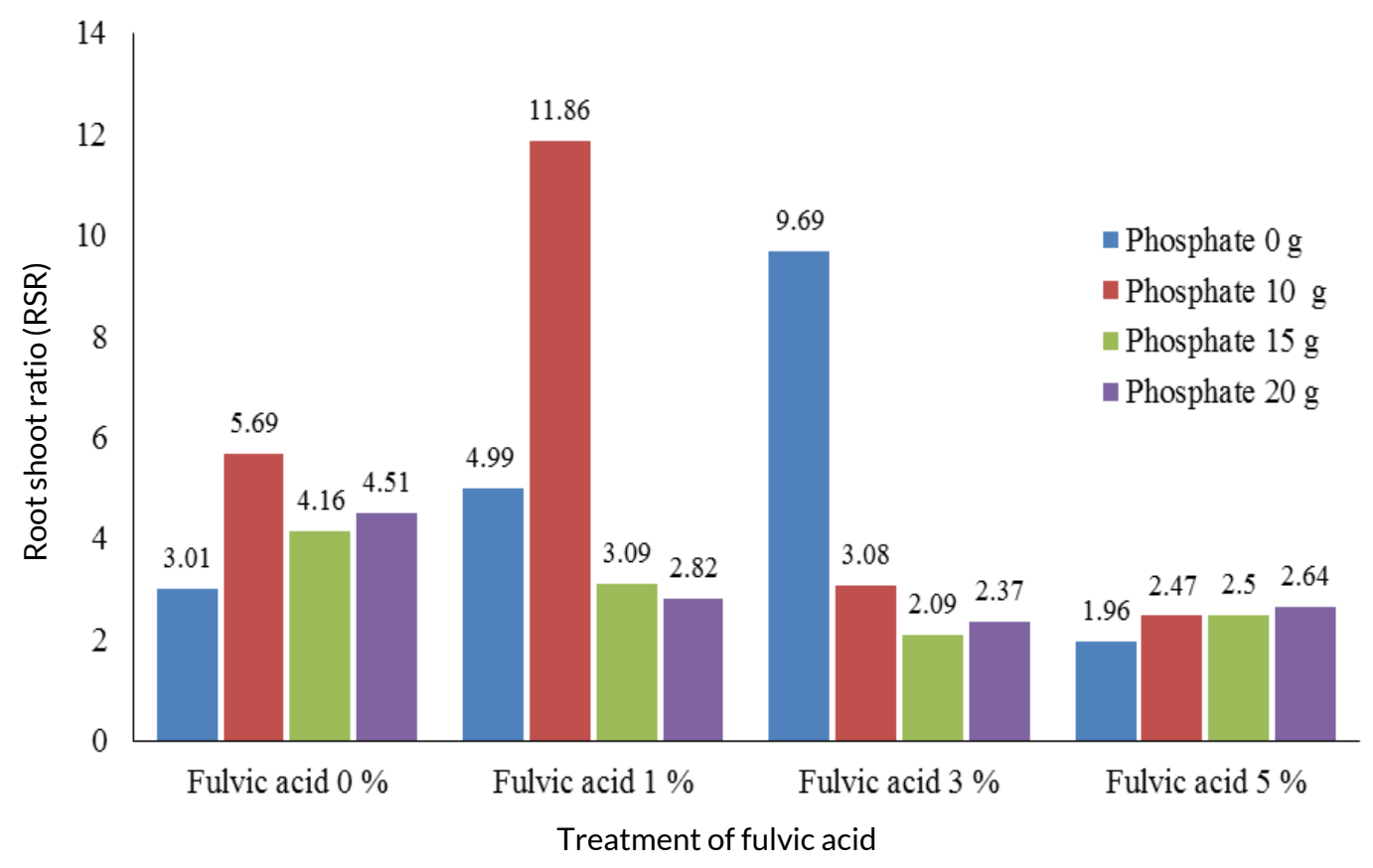

Figure 2. Effect of combination treatment of fulvic acid and phosphate fertilizers on root shoot ratio. 


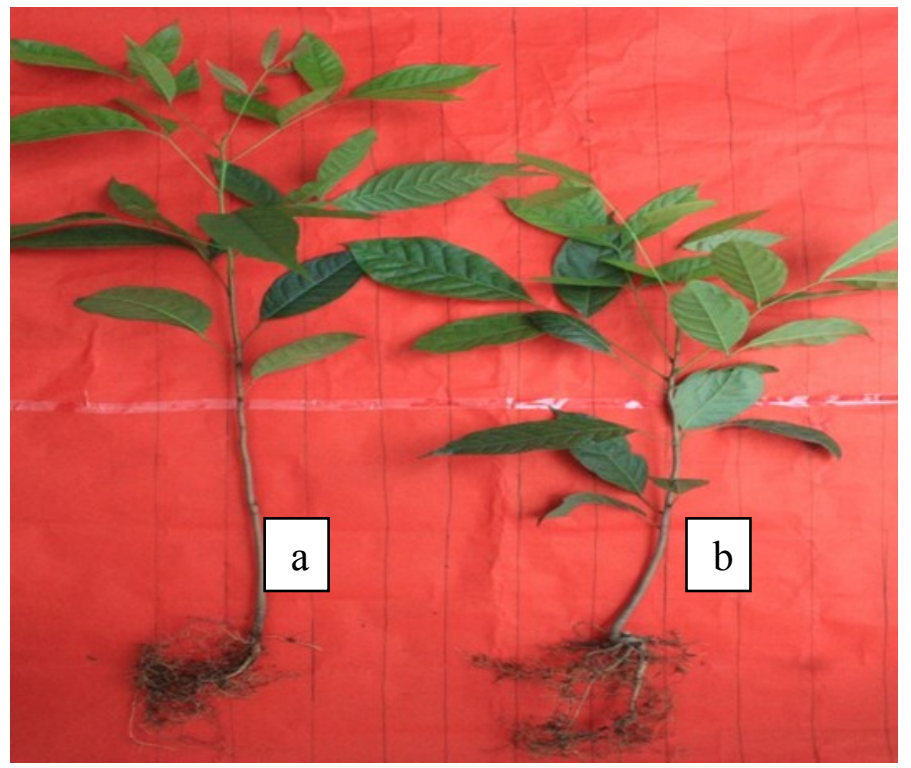

Figure 3. Seedling physical condition of S. macrophylla with treatment (a) $F_{2} P_{3}$ and $(b) F_{0} P_{0}$ (control).

\section{Conclusion}

The treatment of fulvic acid significantly affected the growth of S. macrophylla for parameters of diameter, total dry weight, and root dry weight. The single effect of phosphate fertilizer treatment had a significant effect on high growth, diametert, total wet weight, and total dry weight of S. macrophylla. The interaction of fulvic acid and phosphate fertilizer significantly affected the diameter, total dry weight and root dry weight of $S$. macrophylla. $\mathrm{F}_{2} \mathrm{P}_{3}$ treatment ( $3 \%$ fulvic acid and $20 \mathrm{~g}$ phosphate fertilizer is the best combination treatment. Moreover, addition of fulvic acid and phosphate fertilizer on post mining soil improves soil fertility and decreases Al elements which are toxic to plants.

\section{ACKNOWLEDGEMENT}

We would like to thank to the Forest Ecology Laboratory, Forest Influence Laboratory, and the chairman of Department of Silviculture, Bogor Agricultural Institute (IPB), without their help and support, this research would not have been possible.
Open Access: This is an open access article distributed under the terms of the Creative Commons Attribution 4.0 License, which permits unrestricted use, distribution, and reproduction in any medium, provided the original author(s) if the sources are credited.

\section{REFERENCES}

Ani, S. (2007). Soil Improvement of Citrus Crop Media with Organic Substances in the Form of Compost. [Tesis]. Sekolah Pascasarjana. Institut Pertanian Bogor.

Hardjowigeno, S. (2003). Soil Science (IImu Tanah). Jakarta (ID) : Akademia Pressindo.

Mattjik, A.A. dan Sumertajaya, I.M. ( 2013). Experimental Design with SAS Applications and Minitab. IPB Press. Bogor.

Mokany, K., Raison, R.J., and Prokushkin, A.S. (2006). Critical analysis of root: shoot ratios in terrestrial biomes. Global Change Biology, 12: 84-96, https://doi.org/10.1111/j.1365-2486.2005.001043.x

Prengki S, Fauzi, dan Supriadi. (2017). Pengaruh Pemberian Beberapa Sumber Bahan Organik dan Masa Inkubasi Terhadap Beberapa Aspek Kimia Kesuburan Tanah Ultisol. Journal Agroekoteknologi, 5(2): 256-264. Fakultas Pertanian Universitas Sumatera Utara.

Rahmawati, A. (2011). Pengaruh derajat keasaman terhadap adsorpsi logam Kadmium (II) dan Timbal (II) pada asam humat. Jurnal Penelitian Sains dan Teknologi, 12(1): 1-14.

Stell, R.G.D. and Torries, J.H. (1991). Statistical Principles and Procedures, A Biometric Approach. PT Gramedia Pustaka Utama Jakarta , pp. 149-167

Tan, K.H. (1993). Principless of Soil Chemistry. 2nd ed. Marcel Dekker Inc., New York.

Wasis, B. and Fathia, N. (2011). Growth of gmelina seedlings with various doses of compost fertilizers on the media of former ground gold mine. Journal of Tropical Forest Management, 17 (1): 29-33.

Wasis, B. and Andika, A. (2017). Growth response of mahagony seedling (Swietenia macrophylla King.) to addition of coconut shell charcoal and compost on ex-sand mining site of West Java Province in Indonesia. Agriculture and Environmental Science 2(3): 238-243, https://www.aesacademy.org/journal/volume2/issue3/AAES-02-03-018.p

Wasis, B. and Noviani, D. (2010). Influence of NPK fertilizer and compost on growth seedling jabon (Anthocephalus cadamba Roxb Miq.) gold mining tailing. Journal of Agricultural Science Indonesia, 12(1): 14-19, http://journal.ipb.ac.id/index.php/ JIPI/article/view/6563

Wasis, B., Winata, B. and Andriani, R. (2018). Growth of Agathis dammara (Lamb. Rich.) seedling on gold tailing with addition of coconut shell charcoal and compost. Archives of Agriculture and Environmental Science, 3(2): 131-136, https://doi.org/10.26832/24566632.2018.030205

Wahyudi, I. (2007). Peran asam humat dan fulvat dari kompos dalam detoksifikasi alumunium pada tanah masam. Buana Sains, 7 (2): 123-130. 